\title{
ANALISIS PEMANFAATAN TEKNOLOGI INFORMASI DALAM MANAJEMEN RESIKO BENCANA BANJIR DI KECAMATAN BARUGA
}

\author{
Intan Anuggrah Yuandi, ST., M.PWK \\ Teknik Informatika, Universitas Nahdlatul Ulama Sulawesi Tenggara \\ email: intan.anuggrah@gmail.com
}

\begin{abstract}
Abstrak:Sistem mitigasi banjir saat ini belum bisa bekerja otomatis dan realtime untuk mengetahui ketinggian air sungai. Hal tersebut meyebabkan warga tidak mengetahui saat permukaan air sungai akan meluap. Pada penelitian ini diranang sistem informasi ketinggian air yang bekerja secara otomatis dengan mengetahui ketinggian permukaan air. Sistem ini dirancang dengan mengimplemetasikan sensor ultrasonik dan Arduino uno ATMega32 yang akan mengukur ketinggian air, SMS Gateway sebagai media dalam penyebaran informasi ketinggian ketinggian air dan pemetaan web berbasis GIS. Hasil pengujian dapat disimpulkan bahwa sistem ini dapat bekerja secara realtime dengan tingkat akurasi pembacaan yang dilakukan oleh sensor mencapai $100 \%$, rata-rata delay pengiriman SMS dari sistem 15 detik, rata-rata waktu pengiriman SMS 8,8 detik dan delay pembacaan sensor hingga pembacaan peta 10 detik karena terjadi waktu tunggu untuk pengiriman data dari modul GSM ke modem GSM.
\end{abstract}

Kata Kunci : banjir, sensor ultrasonik, Arduino Uno ATMega 32, sistem informasi, SMS Gateway, Web, GIS

Abstract: Vigilance system about flood not currently able to work with automatic and real-time to determine the height of the water level of the river. This causes around the average citizen does not know when the surface of the river would overflow. In this study designed information system that works automatically by means knowing height the water. This system design by implementing an ultrasonic sensor based Arduino Uno ATMega32 who calculating high of water, SMS Gateway as media for distributing information about high of the water and web mapping based GIS. Test result can be conluding that the system is able to work with the response realtime for reading accuracy to 100\%, averaged of delay for sending SMS from system 15 second, averaged time of sending SMS 8,8 seond and delay of reading sensor to reading mapping 10 second because there was time waiting for sending data from GSM module to GSM modem.

Keywords : Flood, ultrasonic sensor, Arduino Uno ATMega 32, information system, SMS Gateway, Web,GIS

\section{PENDAHULUAN}

Banjir adalah bencana alam yang disebabkan meluapnya air di sungai, danau atau aliran air yang lain, biasanya banjir terjadi pada musim penghujan dengan curah hujan yang cukup tinggi sementara aliran air tidak dapat menampung volume air tersebut sehingga menyebabkan air naik dan menggenangi daratan. Banjir juga dapat terjadi di sungai ketika aliran air melebihi kapasitas saluran air terutama pada kelokan sungai.

Terkait dengan upaya manajemen resiko banjir, perlu penanganan dengan menggunakan teknologi yang bertujuan sebagai peringatan dini akan bencana banjir. Alternatif teknologi manajemen resiko merupakan suatu upaya yang dapat dilakukan dengan memberikan informasi mengenai tinggi muka air sungai kepada masyarakat sehingga secara realtime masyarakat Kecamatan Baruga akan lebih mudah mendapatkan informasi tersebut dan menyiapkan segala keperluannya tanpa perlu mendengarkan kabar yang belum pasti kebenarannya dari orang lain.

Teknologi informasi, adalah bagian dari media yang digunakan untuk menyampaikan pesan pada banyak orang. Kemajuan teknologi yang sangat pesat mengubah gaya hidup manusia menjadi serba mudah dan praktis. Teknologi telepon seluler yang dapat memudahkan seseorang berkomunikasi dengan orang lain dimanapun berada. Salah satu fasilitas dari telepon seluler yang banyak digunakan saat ini adalah SMS (Short Message Service). Hal tersebut dimungkinkan karena berbagai keunggulan dan manfaat yang dimilikinya, diantaranya adalah keunggulan dari segi biaya dan kemudahan penggunaannya di dalam kehidupan sehari-hari.

SMS Gateway merupakan perangkat penghubung antara pengirim SMS dengan basis data. Perangkat ini terdiri dari satu set PC, telepon dan program aplikasi. Penanganan dini bencana banjir berbasis teknologi informasi dipandang perlu diterapkan untuk meminimalisir resiko yang terjadi akibat banjir. Beberapa peneliti sebelumnya telah membangun sistem informasi peringatan dini bencana banjir, yang telah teruji keakurasiannya dalam memberikan informasi peringatan dini banjir. ini adalah:

Adapun tujuan dilaksanakannya penelitian

1. Merencanakan dan membangun sistem informasi dalam manajemen resiko bencana banjir di Kecamatan Baruga.

2. Memberikan informasi kepada pemerintah setempat dan masyarakat di Kecamatan Baruga.

\section{TINJAUAN PUSTAKA}

Penelitian sebelumnya pernah dilakukan oleh [1] Sistem Peringatan Dini Banjir Secara Real-Time Berbasis Web Menggunakan Arduino dan Ethernet. Dalam penelitian ini menggunakan sensor ultrasonik, Arduino Uno, Ethernet shield dan wireless router. Sistem ini dapat mengirimkan data ketinggian air ke pengguna berbasis browser internet, informasi yang ditampilkan berupa data ketinggian air dan status 
banjir yang terdiri atas status aman, waspada dan bahaya.

Penelitan selanjutnya dilakukan oleh [2], Perancangan dan Implementasi Sistem Informasi Geografis: Sistem Pemantauan Banjir Berbasis Android. Sistem pendeteksi pada penelitian ini terdiri dari hardware, database dan software. Pada bagian hardware digunakan mikrokontroler Arduino ATMega328 yang terpasang ultrasonik sensor dan GSM Module Icomsat VI.1, pada bagian database digunakan database MySQL, pada bagian software dibuat sebuah aplikasi pemetaan dan pemantauan banjir berbasis android.

Penelitian selanjutnya dilakukan oleh [3] Perancangan dan Implementasi Sistem Informasi Geografis: Sistem Pemantauan Banjir Berbasis Web, sistem pendeteksi pada penelitian ini terdiri dari hardware, database dan software. Pada bagian hardware digunakan mikrokontroler Arduino ATMega328 yang terpasang ultrasonik sensor dan GSM Module Icomsat VI.1, pada bagian database digunakan database MySQL, pada bagian software dibuat sebuah aplikasi pemetaan dan pemantauan banjir berbasis web. Dari hasil pengujian, sistem ini bekerja secara realtime dan pembacaan peta kurang dari satu detik dengan tingkat akurasi pembacaan oleh sensor ultrasonik sebesar $83.3 \%$ hingga $100 \%$.

Penelitian selanjutnya dilakukan oleh [4], Sistem Pendeteksi Banjir Berbasis Sensor Ultrasonik dan Mikrokontroler dengan Media Komunikasi SMS Gateway. Sistem ini menggunakan sensor ultrasonik berbasis mikrokontroler ATMega 8535 dengan keluaran SMS Gateway dan light voice alarm. Sistem ini akan mengetahui ketinggian permukaan air yang dibuat pada level-level tertentu, hasil uji rancang bangun sistem ini memiliki keakurasian pada sensor ultrasonik yang menghasilkan tingkat rata-rata error $1,21 \%$.

Penelitian selanjutnya dilakukan oleh [5], Analisis dan Perancangan Sistem Pengumpulan Data Bencana Alam. Penelitian ini mengembangkan prototype sistem yang dapat digunakan untuk melakukan pengumpulan data bencana alam melalui piranti mobile. Data yang terkumpul akan disajikan dalam bentuk web dan tertampil pada peta, sehingga memudahkan instansi terkait dalam memantau kondisi bencana dan korban bencana. Penelitian ini memanfaatkan teknologi SMS gateway dan layanan berbasis lokasi dalam implementasinya.

Penelitian selanjutnya dilakukan oleh [6], Aplikasi Informasi Cuaca Dan Gempa Bumi Pada Bmkg Semarang Berbasis Sms Gateway. Aplikasi ini dibangun menggunakan Delphi, XML Engine dan SMS menggunakan Gammu. Aplikasi ini dibangun untuk memberikan informasi berupa informasi cuaca dan gempa pada masyarakat melalui SMS dan memonitoring melalui website.

Penelitian selanjutnya dilakukan oleh [7], Implementasi Sistem Sensor Sederhana Untuk Peringatan Banjir Melalui SMS. Aplikasi ini dibangun menggunakan sensor ultrasonik, relay dan modem GSM. Pada penelitian ini sistem akan mengirimkan SMS jika rangkaian LM339 mengindikasikan bahwa air telah mencapai ketinggian terjadinya banjir.

Penelitian selanjutnya dilakukan oleh [8], Sistem Deteksi Dini Banjir Berbasis Sensor Float Magnetic Level Gauge. Metode float magnetic level gauge adalah salah satu metode yang dapat diterapkan untuk semua jenis pengukuran ketinggian level cairan termasuk ketinggian aliran sungai. Pendeteksi level ketinggian aliran sungai yang dirancang mampu memberikan informasi secara realtime berdasarkan kondisi level ketinggian aliran sungai tersebut, dengan memberikan informasi berupa indikator warning light dan sirene alarm tanda waspada dan bahaya.

Penelitian selanjutnya dilakukan oleh [9], Design Flood Monitoring System Consisting Of A Flood Detector, Display, Monitoring And Short Messages Services. Aplikasi ini dibangun menggunakan sensor waterfall dan Ethernet GSM modem. Sistem monitoring realtime ini dikembangkan untuk memantau perubahan tingkat air dan mengirim peringatan kepada pengguna melalui Global System for Mobile Communication (GSM) jaringan seluler segera setiap kali sistem didefinisikan kondisi waspada terjadi. Sistem ini ditargetkan akan dilaksanakan sebagai peringatan banjir alat oleh pemerintah daerah masing-masing.

Penelitian selanjutnya dilakukan oleh [10], Rancang Bangun Sistem Peringatan Dini Banjir Berbasis Mikrokontroler ATMega32 dan Modem Wavecom RS232. Pada penelitian ini dirancang sebuah alat untuk mendeteksi ketinggian air yang hasilnya akan dikirimkan melalui media transmisi wireless dan akan diterima pada alat yang akan menampilkan kondisi air dijalan yang menjadi langganan banjir.

Penelitian selanjutnya dilakukan oleh [11], Rancang Bangun Pendeteksian Dini Banjir Berbasis Telemetri di Daerah Sampangan Semarang Akibat Luapan Sungai Kaligarang. Pada penelitian ini, pendeteksian dini berbasis telemetri setiap saat akan mengirimkan signal data yang dikumpulkan sebagai database pada komputer yang ditempatkan pada posko. Jika data yang didapatkan melewati batas tinggi permukaan sungai maka sungai atau alarm pada posko akan berbunyi menandakan bahwa 60 (enam puluh) menit kemudian sungai Kaligarang akan mengalami banjir.

Penelitian yang dilakukan penulis, yaitu penyebaran informasi menggunakan GSM Shield sehingga sistemnya ter-otomatisasi mengirimkan SMS dan update web mengenai peringatan banjir, sensor yang digunakan yaitu sensor ultrasonik dan menggunakan hardware Arduino UNO ATMega 32. Pada penelitian ini monitoring ketinggian air untuk mendeteksi banjir berada di bawah jembatan dan dipinggiran kali se-Kecamatan Baruga. 


\section{METODE}

\section{Unified Process (UP)}

Unified Process dikembangkan sebagai metodologi yang bersifat use-case driven, berpusat pada arsitektur, iteratif dan incremental didasarkan pada UML (Unified Modeling Language) yaitu bahasa model standar untuk desain berorientasi objek. Unified Process dikembangkan oleh Rational Software (yang sekarang bagian dari IBM) tahun 1999. Unified Process mendeskripsikan pemberian dan pengelolaan tugas serta tanggung jawab dalam sebuah organisasi pengembang perangkat lunak. Unified Process yang dilaksanakan dengan produkproduk bantu yang dibuat oleh Rational Software (IBM) disebut Rational Unified Process (RUP) [12].

\section{a. Inception}

Tahap inception, adalah tahap persiapan. Halhal yang perlu ditentukan dalam tahap inception ini dalah jadwal kerja, pembentukan tim, dan ruang lingkup perangkat lunak yang akan dikembangkan.

\section{b. Elaboration}

Tahap elaboration, adalah tahap perencanaan dimana penekanan dilakukan pada terselesaikannya deskripsi kebutuhan perangkat lunak, analisis dan desain arsitektur, serta pembangunan kerangka dasar aplikasi dan metode pengujiannya.

\section{c. Construction}

Tahap construction, adalah tahap pembangunan yang dilakukan penekanan pada desain teknis, pemrograman dan pengujian perangkat lunak. d. Transition

Tahap transition, adalah tahap penerapan dilakukannya uji coba oleh calon pengguna, pelatihan, persiapan pemakaian dan diakhiri dengan pemakaian sistem oleh pengguna.

\section{Unified Modeling Language (UML)}

Unified Modeling Language (UML), adalah salah satu standar bahasa yang banyak digunakan di dunia industri untuk mendefinisikan kebutuhan, membuat analisis dan desain, serta menggambarkan arsitektur dalam pemrograman beorientasi objek UML muncul karena adanya kebutuhan pemodelan visual untuk menspesifikasikan, menggambarkan, membangun dan dokumentasi dari sistem perangkat lunak. [12].

\section{a. Use Case Diagram}

Use case diagram mengambarkan fungsionalitas yang diharapkan dari sebuah sistem, yang ditekankan adalah apa yang diperbuat sistem dan bukan bagaimana. Use case merupakan sebuah pekerjaan tertentu, misalnya login ke sistem, mengcreate sebuah daftar belanja dan sebagainya. Seorang aktor adalah sebuah entitas manusia atau mesin yang berinteraksi dengan sistem untuk melakukan pekerjaan-pekerjaan tertentu [13].

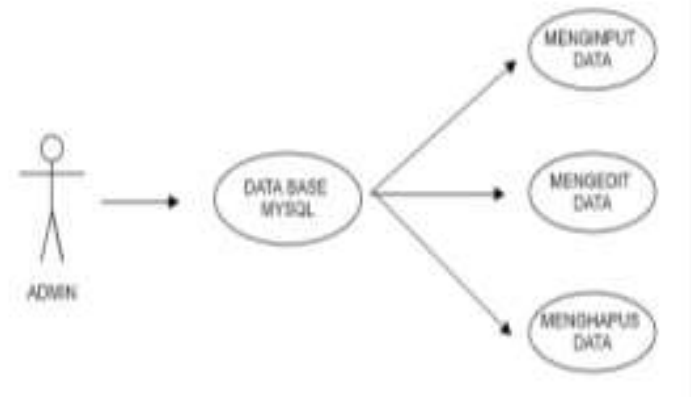

Gambar 1. Use Case Diagram Sistem

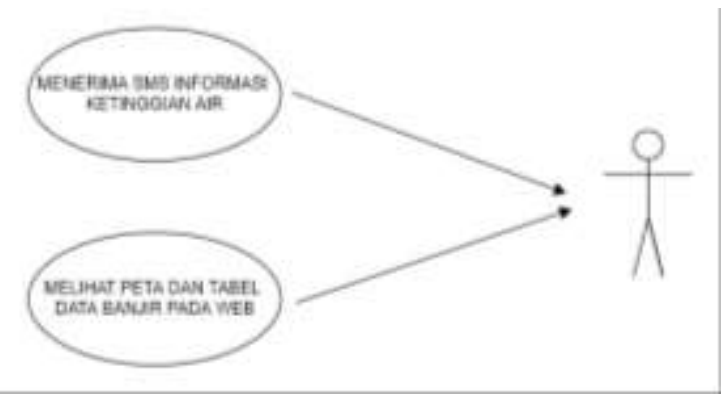

Gambar 2. Use Case Diagram User

\section{Class Diagram}

Class adalah sebuah spesifikasi yang jika diinstansiasi akan menghasilkan sebuah objek dan merupakan inti dari pengembangan dan desain berorientasi objek. Class menggambarkan keadaan (atribut/properti) suatu sistem, sekaligus menawarkan layanan untuk memanipulasi keadaan tersebut (metoda/fungsi) [13].

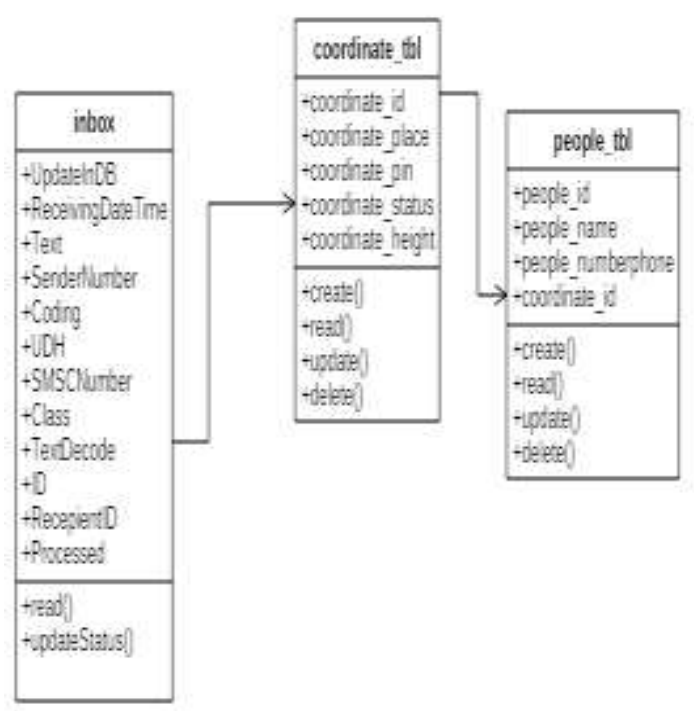

Gambar 3. Class Diagram System

\section{Activity Diagram}

Activity diagram, menggambarkan berbagai alir aktivitas dalam sistem yang sedang dirancang, bagaimana masing-masing alir berawal, decision yang mungkin terjadi dan bagaimana berakhirnya. Activity diagram juga dapat menggambarkan proses paralel yang mungkin terjadi pada beberapa eksekusi. Activity diagram merupakan state diagram khusus dimana sebagian besar state adalah action dan 
sebagian besar transisi di-trigger oleh selesainya state sebelumnya (internal processing). [13].

a. Activity Diagram Basis Data

Meng-input database merupakan kegiatan untuk masuk ke dalam sistem agar dapat mengakses, menjalankan fungsi dan fitur yang tersedia.

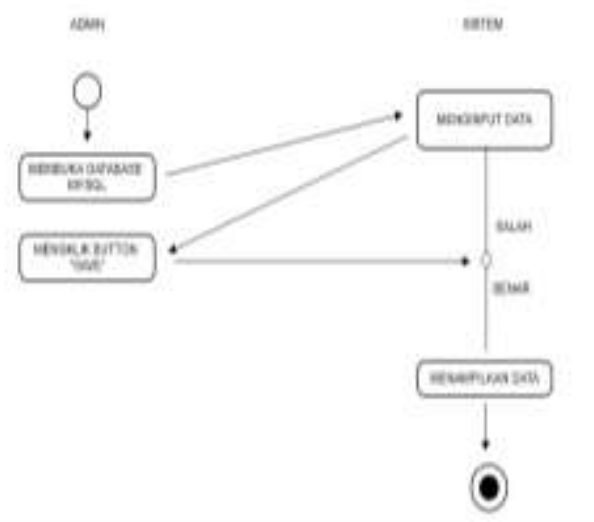

Gambar 4. Activity diagram Basis Data

b. Activity Diagram Sistem

Activity diagram menggambarkan aliran aktivitas dalam sistem yang sedang dirancang.

\section{Perancangan Sistem}

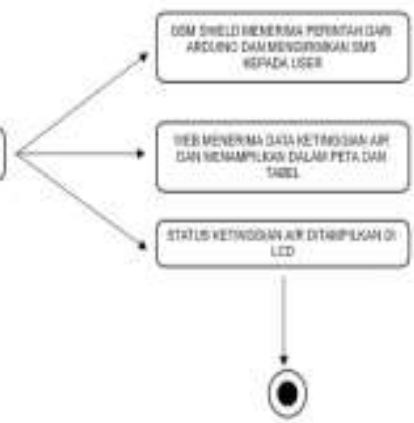

Penelitian ini dimulai dengan merangkai alat yakni sensor ultrasonik, ld, mikrokontroler dan GSM Shield. Peneliti melakukan observasi untuk mengetahui tingkat ketinggian air normal dan tingkat ketinggian air yang berpotensi menimbulkan banjir di beberapa titik di kecamatan Baruga. Perancangan sistem harus mempertimbangkan beberapa kondisi dikarenakan perangkat yang digunakan dalam penelitian ini masih memiliki keterbatasan seperti jarak pengukuran sensor ultrasonik yang memiliki range $3 \mathrm{~cm}-4 \mathrm{~m}$.

\section{Perancangan Mekanik}

Gambaran perancangan mekanik sistem dalam manajemen resiko bencana banjir, yakni:

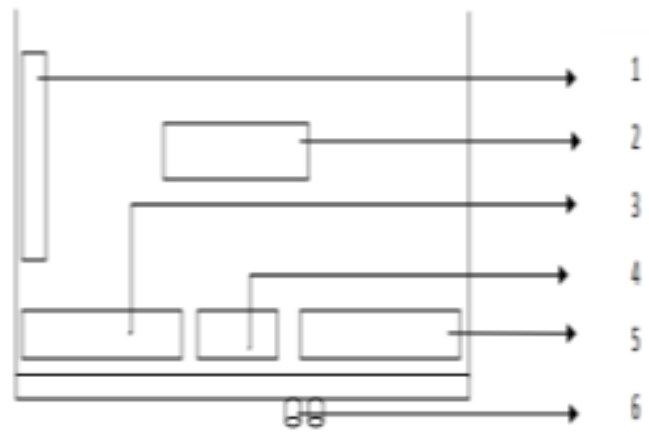

Gambar 6. Perancangan mekanik sistem Keterangan:

1. Baterai

2. Lcd

3. Arduino Uno

4. Breadboard

5. GSM Shield

6. Sensor Ultrasonik

\section{Perancangan Elektronik}

Desain sistem dalam manajemen resiko bencana banjir dibuat skematik rangkaian berupa hubungan antara mikrokontroler dengan komponenkomponen pendukung lainnya. Data diproses oleh mikrokontroler melalui pin-pin yang ada, sensor ultrasonik ditempatkan pada port 3 dan 4, GSM Shield ditempatkan pada port 7 dan 8. $L C D$ berada pada port A4 dan A5, buzzer ditempatkan pada port 9 dan Led merah berada pada port 10 .

\section{Perancangan Software}

Software yang digunakan untuk membuat program pada mikrokontroler yakni Arduino IDE yang menggunakan bahasa Arduino. Implementasi pemodelan ke mikrokontroler dilakukan dengan membuat flowchart.

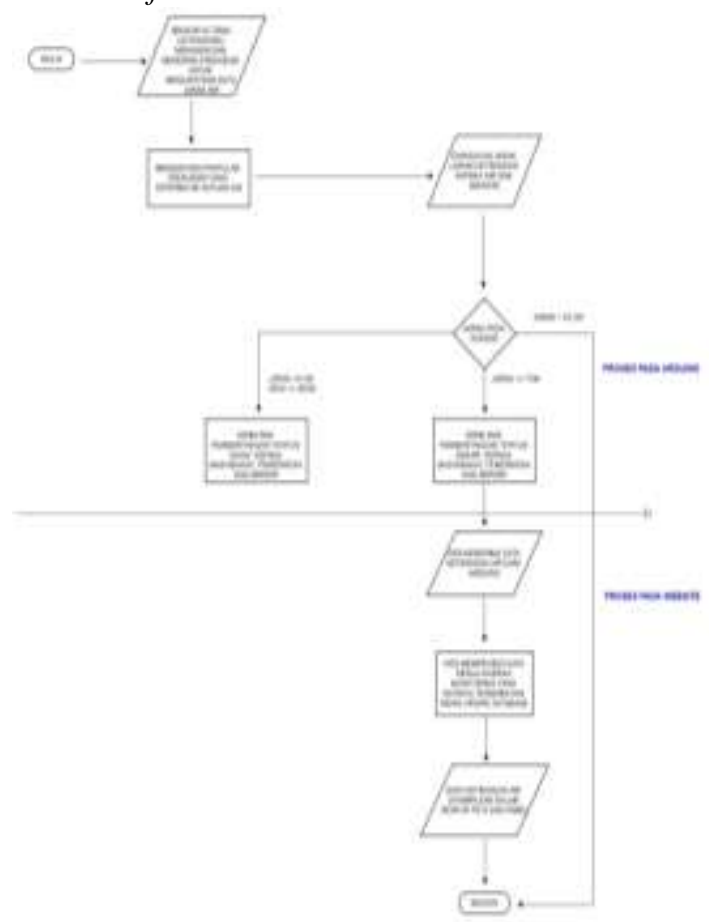

Gambar 7. Flowchart 


\section{Skema Rangkaian}

GSM Shield menggunakan jalur VUART (Virtual Universal Asnyhorus Receiver Transmitter) agar bisa tersambung langsung dengan ATMega 32 sehingga mikrokontroler dapat terkoneksi dengan GSM Shield melalui pin dan 7 dan 8. Pin 7 akan menerima perintah dari mikrokontroler untuk data pengiriman SMS, pin 8 memproses data pengiriman SMS dari mikrokontroler yang dihubungkan dengan inputan nomor tujuan SMS dari mikrokontroler lalu mengeksekusi perintah dari mikrokontroler untuk mengirimkan SMS ke nomor tujuan dari mikrokontroler, pin 9 untuk buzzer dan pin 10 untuk penempatan lampu Led.

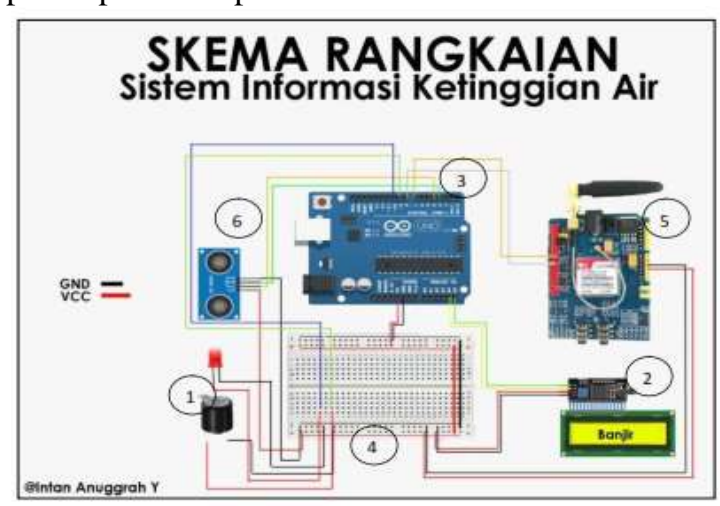

$$
\begin{array}{ll}
\text { Keterangan: } \\
\text { 1. } & \text { Baterai } \\
\text { 2. } & \text { Lcd } \\
\text { 3. } & \text { Arduino Uno } \\
\text { 4. } & \text { Breadboard } \\
\text { 5. } & \text { GSM Shield } \\
\text { 6. } & \text { Sensor Ultrasonik }
\end{array}
$$

\section{HASIL DAN PEMBAHASAN}

\section{Pengujian Sensor Ultrasonik}

Sensor ultrasonik ini terdiri dari dua rangkaian yang bekerja sebagai pemancar ultrasonik (echo) dan rangkaian penerima (trig). Rangkaian sensor yang berfungsi sebagai pemancar (echo) akan memancarkan gelombang ultrasonik dengan frekuensi tertentu, kemudian apabila terjadi benturan terhadap suatu benda atau objek maka gelombang ultrasonik akan dipantulkan kembali dan diterima oleh rangkaian sensor yang berfungsi sebagai penerima (trig). Jarak minimal sensor ultrasonik adalah $3 \mathrm{~cm}$ dan jarak maksimal adalah $4 \mathrm{~m}$.

Cara kerja dari sensor ini adalah pada saat ketinggian air masih dangkal maka led tidak menyala bertanda bahwa ketinggian air masih dalam level normal dengan ketinggian maksimum sampek $400 \mathrm{~cm}$, lalu setelah itu ketika ketinggian air bertambah maka led merah akan berkedip sesekali dan buzzer berbunyi sesekali petanda bahwa ketinggian level air berubah menjadi siaga dengan ketinggian air maksimum $20 \mathrm{~cm}$, ketika air bertambah lagi maka led merah menyala disertai buzzer berbunti menandakan bahwa level ketinggian air sudah masuk status banjir yang berarti sudah mencapai titik maksimal untuk mencapai banjir dengan ketinggian air maksimal $7 \mathrm{~cm}$.

\section{Pengujian Pengiriman SMS}

Pengujian pengiriman SMS bertujuan untuk mengetahui seberapa akurat dan sukses sistem ini dalam pengiriman informasi. Pengujian dilakukan dengan megaktifkan AT-Command pada mikrokontroler untuk megirimkan SMS ke nomor telepon tujuan.

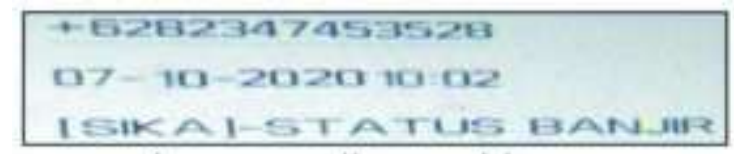

Gambar 9. Pengujian Pengiriman SMS

\section{Pengujian Web}

Pengujian web perlu dilakukan sebelum web tersebut digunakan. Pengujian merupakan salah satu bagian yang penting dalam menjamin kualitas halaman web. Pengujian ini dilakukan untuk menemukan kesalahan yang disebabkan oleh proses perancangan maupun implementasi yang belum tepat.

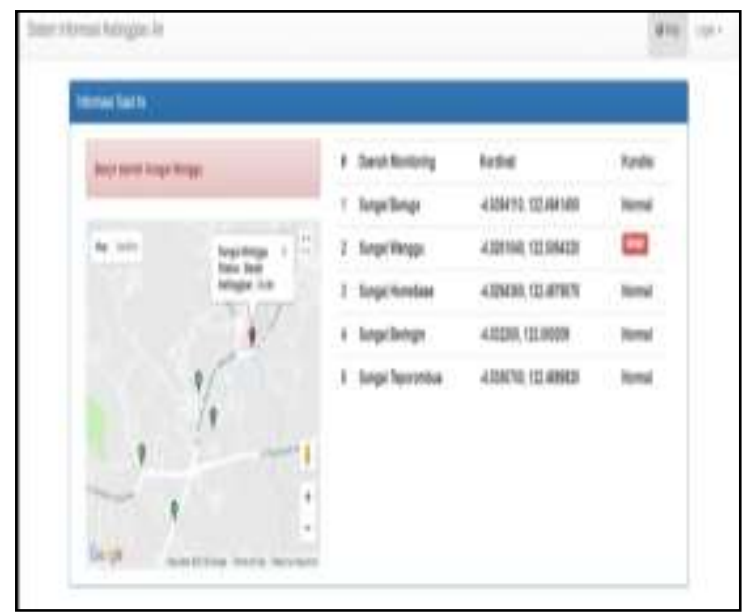

Gambar 10. Tampilan Web Ketika Banjir

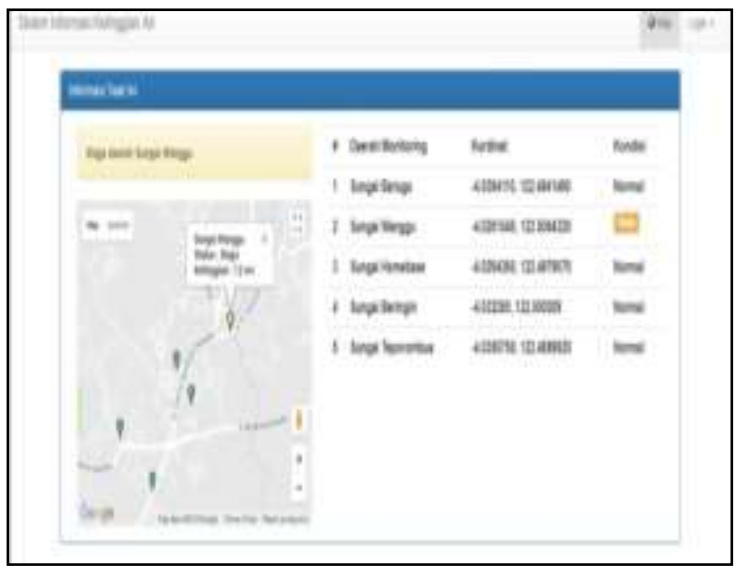

Gambar 11. Tampilan Web Ketika Siaga

\section{Pengujian Sistem Seara Keseluruhan}

Pengujian sistem secara keseluruhan dilakukan untuk mengetahui kinerja sistem secara keseluruhan. Pengujian ini dilaksanakan dengan memasang sistem di tempat pengujian, dalam hal ini pada tepi jembatan yang terletak pada Jl. Mayjend Katamso, Jl. Piere Tendean, Jl. Christina Marta Tiahahu, Jl. Ade Irma Nasution dan J1. H. La Muse dalam beberapa waktu untuk memantau kondisi air 
Vol. 3 No. 1, Februari 2021, hlm. 260 - 266

dengan menyesuaikan aspek pengujian. Pengujian juga dilakukan dengan ujioba pada ember sebagai wadah air. Pengamatan ini dilakukan dengan mengamati dan mengukur jarak antara sensor dan permukaan air, tampilan $L C D$, durasi pengiriman pesan dan update web.

\begin{tabular}{|c|c|c|c|c|c|}
\hline \multirow{2}{*}{ No } & \multirow{2}{*}{$\begin{array}{c}\text { Masukan } \\
\text { Jarak } \\
\text { sensor (cm) }\end{array}$} & \multicolumn{4}{|c|}{ Keluaran } \\
\hline & & Pesan & Status SMS & LCD & Web \\
\hline 1 & 612 & - & - & $\begin{array}{l}\text { Nomal } \\
612 \mathrm{~cm}\end{array}$ & Tidak update \\
\hline 2 & 453 & - & - & $\begin{array}{l}\text { Nocmal } \\
453 \mathrm{~cm}\end{array}$ & Tidak update \\
\hline 3 & 320 & - & - & $\begin{array}{l}\text { Nomal } \\
320 \mathrm{~cm}\end{array}$ & Tidak update \\
\hline 4 & 218 & - & - & $\begin{array}{l}\text { Normal } \\
218 \mathrm{~cm}\end{array}$ & Tidak update \\
\hline 5 & 250 & - & - & $\begin{array}{l}\text { Normal } \\
250 \mathrm{~cm}\end{array}$ & Tidak update \\
\hline
\end{tabular}

Tabel 1. Pengujian Secara Keseluruhan dengan Ketinggian Air Normal

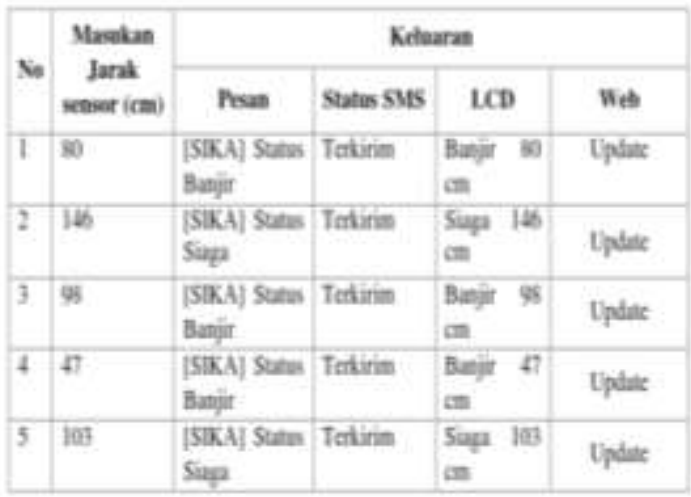

Tabel 2. Pengujian Secara Keseluruhan dengan Kondisi Hujan Deras

Pengujian sistem dilakukan pada 5 titik sungai/kali pada kondisi ketinggian air normal dan pada saat hujan deras. Hasil pengujian ketinggian air dapat dilihat pada gambar berikut.

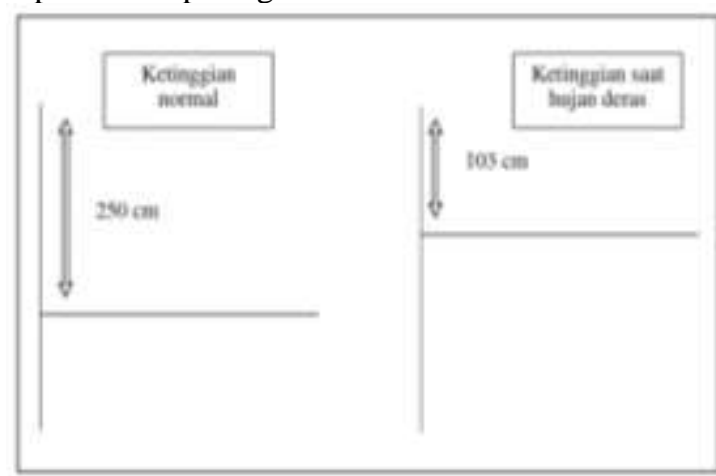

Gambar 11. Ketinggian Air di Kali Teporombua (Jl. Piere Tendean)

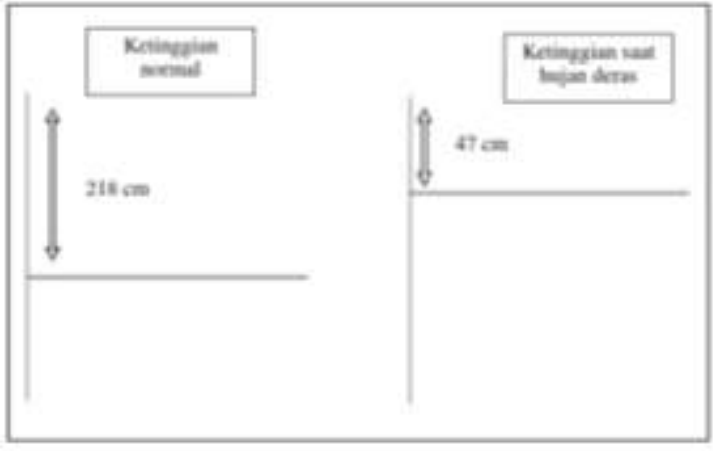

Gambar 12. Ketinggian Air di Kali Jl. Mayjend Katamso

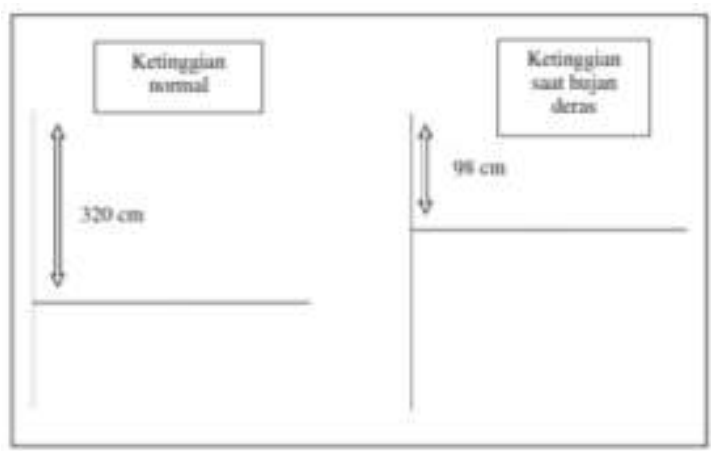

Gambar 13. Ketinggian Air di Kali Beringin (Christina M. Tiahahu)

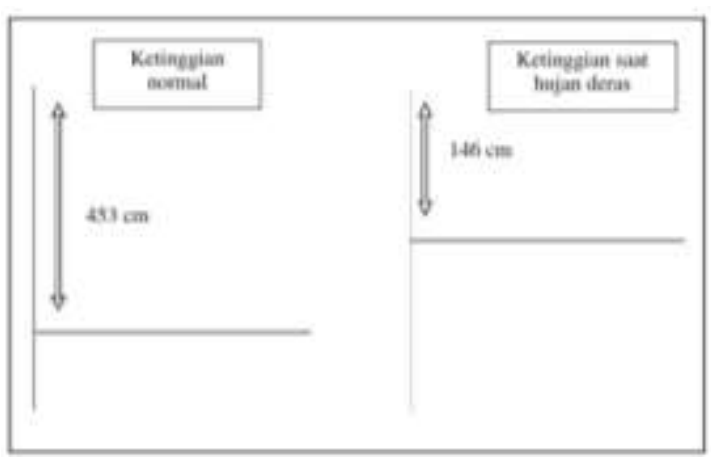

Gambar 14. Ketinggian Air di Kali Hombis (Jl. Ade Irma Nasution)

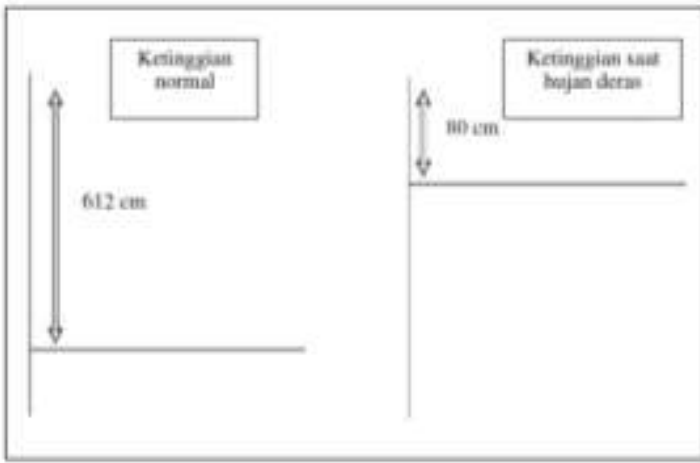

Gambar 15. Ketinggian Air di Sungai Wanggu

\section{KESIMPULAN DAN SARAN \\ Kesimpulan}

Berdasarkan hasil penelitian dan implementasi sistem ini, maka dapat disimpulkan bahwa:

1. Sistem informasi manajemen resiko bencana banjir di Kecamatan Baruga dibangun dengan mengintegrasikan kinerja dari sensor ultrasonik, Arduino Uno ATMega32, GSM Shield, 
mikrokontroler, LCD, SMS Gateway dan web GIS.

2. Sistem informasi manajemen resiko banjir di Kecamatan Baruga telah diimplementasikan dan dapat memberikan informasi yang optimal kepada pemerintah dan masyarakat setempat.

\section{Saran}

Berdasarkan hasil penelitian dan implementasi sistem ini, maka penulis memberikan saran:

1. Dapat menggunakan sensor selain sensor ultrasonik, yakni sensor pendeteksi benda dan suhu.

2. Dapat menggunakan kamera untuk memonitoring langsung kondisi permukaan air dan kondisi sistem dilapangan.

3. Sistem ini dapat diimplementasikan oleh instansi terkait, dalam hal manajemen resiko bencana banjir.

4. Penggunaan sistem ini dapat diterapkan cash bagi penerima SMS.

\section{DAFTAR PUSTAKA}

[1] Dedi, Satria. 2017. Sistem Peringatan Dini Banjir Secara Real-Time Berbasis Web Menggunakan Arduino dan Ethernet. Universitas Serambi Mekkah. Halaman 1-6.

[2] Perdana, Erik Oktafianto. 2015. Perancangan dan Implementasi Sistem Informasi Geografis: Sistem Pemantauan Banjir Berbasis Android. Universitas Telkom. Halaman 1-8

[3] Taufik, Ismail. 2015. Perancangan dan Implementasi Sistem Informasi Geografis: Sistem Pemantauan Banjir Berbasis Web. Universitas Telkom. Halaman 1-8.

[4] Sulistyowati, Rini ddk. 2015. Sistem Pendeteksi Banjir Berbasis Sensor Ultrasonik dan Mikrokontroler dengan Media Komunikasi SMS Gateway. Seminar Nasional Sains dan Terapan III 2015. Institut Teknologi Adhi tama. Surabaya.

[5] Theresia, Devi Indriasari. 2014. Analisis dan Perancangan Sistem Pengumpulan Data Bencana Alam. Universitas Atma Jaya Yogyakarta. Halaman $1-10$.

[6] Purwanto, P. (2013). Aplikasi Informasi Cuaca Dan Gempa Bumi Pada Bmkg Semarang Berbasis Sms Gateway (Doctoral dissertation), UNIVERSITAS STIKUBANK (UNISBANK)).

[7] Samijayani, O. N., Iftikar, F., Hariomurti, M., dan Astharini, D. 2014. Implementasi Sistem Sensor Sederhana Untuk Peringatan Banjir Melalui Sms. Seri Sains Dan Teknologi, 2(1), Halaman 22-27.

[8] Fahrul, Miranti, Ambo Asse dan Yuli Asmi Rashman. 2013. Sistem Deteksi Dini Banjir Berbasis Sensor Float Magnetic Level Gauge. Universitas Tadulako. Halaman 1-5.

[9] Baharum, M. S., Awang, R. A., \& Baba, N. H. 2011. Flood Monitoring System (MyFMS). In System Engineering and Technology (ICSET), 2011 IEEE International Conference on IEEE. Halaman 204208.

[10] Maulana, Jati. 2010. Rancang Bangun Sistem Peringatan Dini Banjir Berbasis Mikrokontroler ATMega32 dan Modem Wavecom RS232. Universitas Indonesia. Halaman 1-14.
[11] Rochani, I., Bono, Suwoto, G. 2007. Rancang Bangun Pendeteksian Dini Banjir Berbasis Telemetri Di Daerah Sampangan Semarang Akibat Luapan Sungai Kaligarang. Semarang. Halaman 1-6.

[12] Rosa, A. S., dan Salahuddin, M, 2013, Modul Pembelajaran Rekayasa Perangkat Lunak (Terstruktur dan Berorientasi Objek), Informatika, Bandung.

[13] Nugroho, 2005, Rational Rose untuk Pemodelan Berorientasi Objek, Informatika, Bandung. 